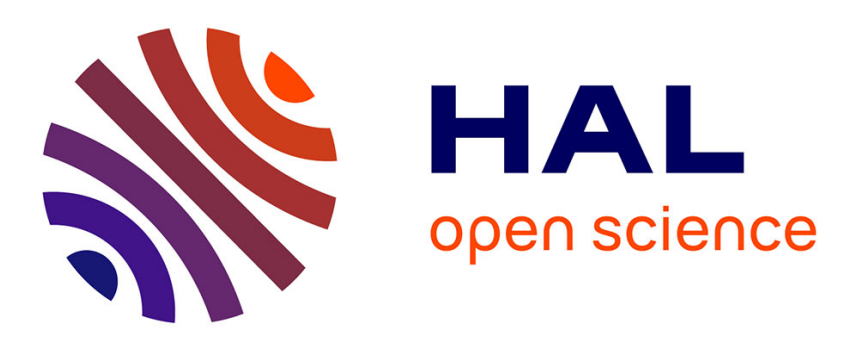

\title{
Intercalation of tetrathiafulvalene between the two plates of a copper(I)-complexed [4] rotaxane
}

\author{
J.-P. Sauvage, Y. Trolez, David Canevet, Marc Sallé
}

\section{To cite this version:}

J.-P. Sauvage, Y. Trolez, David Canevet, Marc Sallé. Intercalation of tetrathiafulvalene between the two plates of a copper(I)-complexed [4]rotaxane. European Journal of Organic Chemistry, 2011, pp.2413-2416. 10.1002/ejoc.201100142 . hal-03344626

\section{HAL Id: hal-03344626 \\ https://univ-angers.hal.science/hal-03344626}

Submitted on 15 Sep 2021

HAL is a multi-disciplinary open access archive for the deposit and dissemination of scientific research documents, whether they are published or not. The documents may come from teaching and research institutions in France or abroad, or from public or private research centers.
L'archive ouverte pluridisciplinaire HAL, est destinée au dépôt et à la diffusion de documents scientifiques de niveau recherche, publiés ou non, émanant des établissements d'enseignement et de recherche français ou étrangers, des laboratoires publics ou privés. 


\title{
Intercalation of Tetrathiafulvalene between the Two Plates of a Copper(I)- Complexed [4]Rotaxane
}

\author{
Jean-Pierre Sauvage, ${ }^{*[a]}$ Yann Trolez, ${ }^{[a]}$ David Canevet, ${ }^{[b]}$ and Marc Sallée[b]
}

Keywords: Rotaxanes / Host-guest systems / Receptors / Supramolecular chemistry

The ability of a cyclic copper(I)-complexed [4]rotaxane to act as a receptor towards organic electron donors has been studied. In particular, tetrathiafulvalene (TTF), which is a flat and electron-rich molecule, forms a relatively stable complex with the rotaxane host. ${ }^{1} \mathrm{H}$ NMR spectroscopic measurements strongly suggest that the coordination mode involves intercalation of the TTF motif between the two electron-poor plates of the [4]rotaxane. By contrast, extended TTF (exTTF), which possesses $\pi$-donating ability similar to that of TTF but which is a significantly bulkier molecule due to a concave structure, was not able to form any detectable complex. This observation tends to indicate that the recognition site of the [4] rotaxane receptor is rigid and can not adapt to thick substrates.

\section{Introduction}

Tetrathiafulvalene (TTF, 2) and related organic donors are particularly important as components of new molecular materials displaying novel electronic or magnetic properties. ${ }^{[1]}$ TTF derivatives have also been incorporated into large molecular systems aimed at behaving as receptors or in catenanes and rotaxanes with the aim of preparing molecular machine like molecules. ${ }^{[2]}$ Whereas the use of TTF as a component of large organic receptors seems to be well documented, ${ }^{[3]}$ there are relatively few reports on the complexation of TTF itself by organic hosts. Only two general types of TTF receptors, cyclobis(paraquat-p-phenylene) $\mathrm{CBPQT}^{4+}$ or "blue box" and a molecular capsule of Rebek's group, have been described up to date. ${ }^{[4]}$ Our group has recently reported the synthesis of copper(I)-complexed [3]- or [4] rotaxanes and their use as receptors for various ditopic substrates containing exo pyridyl groups as terminal functions. ${ }^{[5,6]}$ In this case, the host contains two plates in between which the substrate can be accommodated, these plates consisting of electron-rich groups (zinc-complexed porphyrins). A related compound was prepared whose electronic properties are very different. The aromatic plates are in this case strongly electron deficient and were expected to be able to interact with electron-rich species. TTF (2) and extended TTF (exTTF, 3 ) appeared to be promising candidates in this respect. We would now like to report our pre-

\footnotetext{
[a] Laboratoire de Chimie Organo-Minérale, Institut de Chimie, LC3 UMR 7177 du CNRS, Université de Strasbourg, 4 rue Blaise Pascal, 67070 Strasbourg Cedex, France E-mail: sauvage@chimie.u-strasbg.fr

[b] Laboratoire MOLTECH-Anjou,

UMR CNRS 6200, Université d'Angers,

2 Bd Lavoisier, 49045 Angers, France

E-mail: marc.salle@univ-angers.fr

Supporting information for this article is available on the
} WWW under http://dx.doi.org/10.1002/ejoc.201100142. liminary results on recognition of a flat aromatic donor such as TTF by [4]rotaxane $\mathbf{1}^{4+}$ represented in Figure 1. By contrast, a bulkier electron-donating group such as $\mathbf{3}$ does not seem to form complexes with the same receptor, as it cannot be inserted between the two plates of $\mathbf{1}^{4+}$.
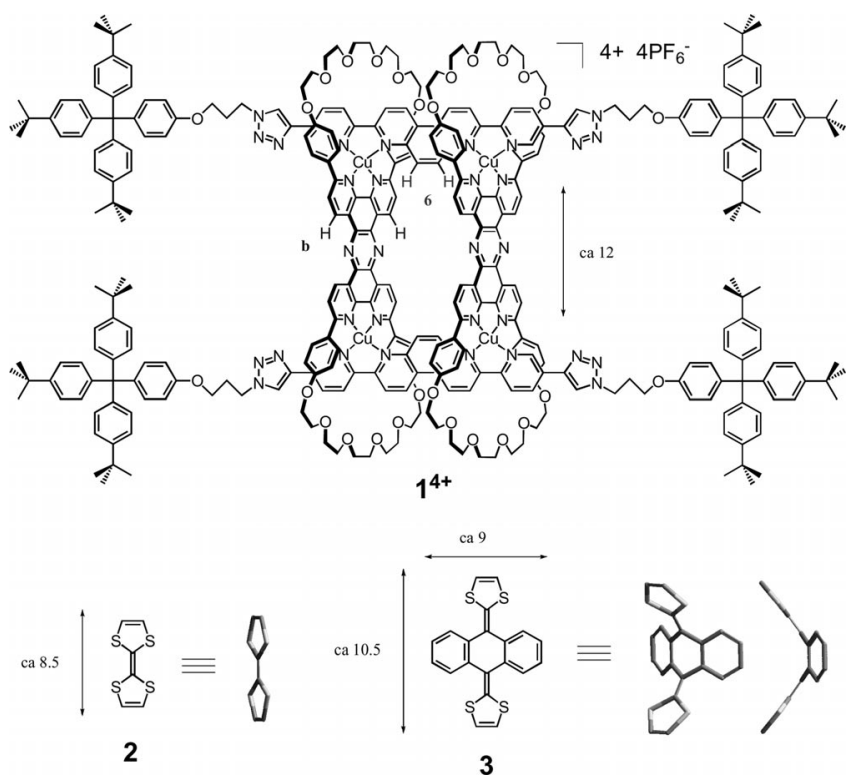

Figure 1. Chemical structures of compounds $\mathbf{1}^{4+}, \mathbf{2}$, and $\mathbf{3}$; optimized geometries of compounds $\mathbf{2}$ and $\mathbf{3}$ are also presented (semiempirical method PM3).

\section{Results and Discussion}

Rotaxane $\mathbf{1}^{4+}$ and exTTF (3) were synthesized according to literature procedures, ${ }^{[6 a, 7]}$ whereas TTF was commercially available and used without any further purification. 
The intercalation process with rotaxane $\mathbf{1}^{4+}$ and a flat aromatic donor has been envisaged for two reasons. (i) The central parts of the bismacrocycles of rotaxane $1^{4+}$ have a pronounced electron-deficient character due to the presence of the pyrazine groups. Moreover, the coordination of metallic cations such as $\mathrm{Cu}^{\mathrm{I}}$ to both 1,10-phenanthroline units increases their electron-deficient character. (ii) According to the previously reported crystallographic structure of a related [4]pseudorotaxane containing exactly the same bismacrocycles and analogous but slightly different axles, ${ }^{[8]}$ the distance between the two planes defined by the pyrazine spacers is about $7.2 \AA$, which is optimal to envision intercalation of a planar guest molecule such as TTF through donor-acceptor or $\pi-\pi$ interactions.

The potential intercalation of compounds $\mathbf{2}$ and $\mathbf{3}$ was investigated by ${ }^{1} \mathrm{H}$ NMR spectroscopy at room temperature. Addition of 2 (1 equiv.) to a solution containing [4]rotaxane $\mathbf{1}^{4+}(4 \mathrm{mg})$ in $\mathrm{CD}_{2} \mathrm{Cl}_{2} \quad(0.5 \mathrm{~mL}, \quad c=$ $1.3 \times 10^{-3} \mathrm{~mol} \mathrm{~L}^{-1}$ ) induced a slight chemical shift of some protons of the rotaxane, in particular protons $6-\mathrm{H}$ and $\mathrm{b}-$ $\mathrm{H}$. But the most striking observation was that no signal could be attributed to the protons of TTF. Though the addition of several equivalents of TTF continued to displace the signals of protons $6-\mathrm{H}$ and $\mathrm{b}-\mathrm{H}$, the appearance of TTF protons could only be observed when adding up to 37 equiv. of donor guest. With such a large excess, the emergence of a very broad peak in the free TTF chemical shift region in $\mathrm{CD}_{2} \mathrm{Cl}_{2}$ was observed. This broad peak grew with the addition of more TTF until about 80 equiv. This observation tends to indicate that there are two types of TTF in equilibrium in solution (one which is free and the other which is intercalated between the two aromatic plates offered by the rotaxane) but that only an average signal is observed. The fact that the signals of both types of TTF (free and complexed) could not be detected separately is explained by the kinetics of the complexation-decomplexation process which was too fast for the NMR timescale. Moreover, the intercalation of TTF (Figure 2) in between the two plates is expected to induce an important upfield shift of the guest protons. Because the $\mathrm{H}$ signals of intercalated TTF and free TTF have very different chemical shifts, it was anticipated that the averaged signal is very broad, which was observed.

The other observation that definitely proved this intercalation process was the downfield shift of the 6-H proton signal. This proton belongs to the central part of the axles and it points towards the cavity. It will thus be very sensitive to events taking place within the cavity or close to it. A few ${ }^{1} \mathrm{H}$ NMR spectra obtained in the course of the titration of $\mathbf{1}^{4+}$ by TTF are represented in Figure 3. Indeed, progressive addition of TTF to the solution shifted the 6-H proton from $7.48 \mathrm{ppm}$ (without TTF) to $7.60 \mathrm{ppm}$ (with a very large excess amount of TTF), which was the largest shift observed for the protons of the rotaxane. This observation is a strong indication that complexed TTF was situated inside and not outside the cavity. The downfield shift observed for the 6-H proton upon addition of TTF can be explained by the proximity of one molecule of TTF. The second pro- (a)

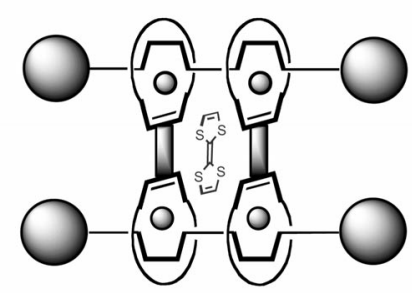

(b)

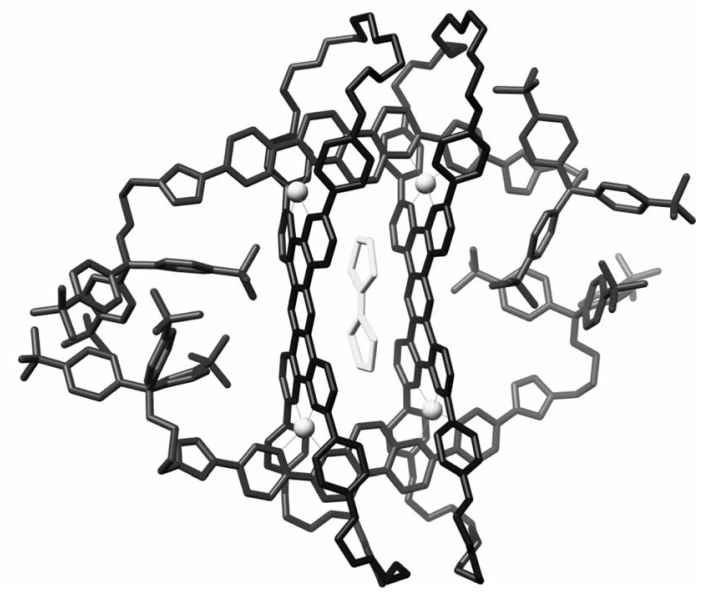

Figure 2. Intercalation of TTF 2 in [4] rotaxane $\mathbf{1}^{4+}$ : (a) schematic representation and (b) optimized geometry of the complex formed between $\mathbf{1}^{4+}$ and $\mathbf{2}$ (AMBER method).

ton that was perturbed during the titration was the $\mathrm{b}-\mathrm{H}$ proton, which belongs to the 1,10-phenanthroline nuclei of the bismacrocycles. This proton, which is also close to the complexation site of the receptor, was slightly upfield shifted from 9.96 to $9.89 \mathrm{ppm}$. Once again, this observation was in accordance with the proposed structure of the complex formed between the [4]rotaxane and TTF.

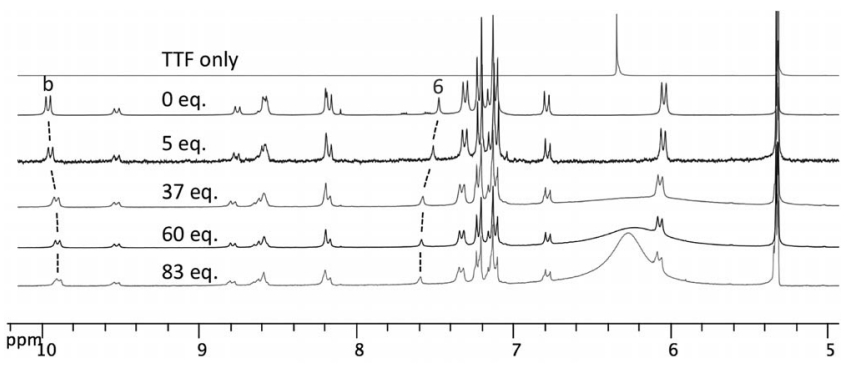

Figure 3. Evolution of the ${ }^{1} \mathrm{H}$ NMR spectrum of [4]rotaxane $\mathbf{1}^{4+}$ ( $\left.c=1.3 \times 10^{-3} \mathrm{~mol} \mathrm{~L}^{-1}\right)$ upon addition of TTF in $\mathrm{CD}_{2} \mathrm{Cl}_{2}$ at room temperature; $n$ eq. indicates the number of equivalents of TTF added.

As already stated, the crystallographic structure of a related [4]pseudorotaxane indicated that the distance between the two planes defined by the two plates of the bismacrocycles is about $7.2 \AA$, which explains the perfect fit for $\pi$ stacking with TTF. The insertion of a dimer of TTF into the cavity cannot be envisaged because of the high rigidity of the host. Moreover, modeling of the complex (AMBER 
method) ruled out the possibility to insert two TTF at the same time inside the cavity. It should be noticed that complexation of TTF dimers has been observed in other cases, with large electron-deficient receptors. ${ }^{[9]}$

The association constant of the complexation equilibrium was determined by using the Benesi-Hildebrand method applied to NMR spectroscopy. ${ }^{[10]}$ Indeed, if we consider the following equilibrium:

$\mathrm{H}+\mathrm{G} \rightleftarrows \mathrm{H} \cdot \mathrm{G}$

where $\mathrm{H}$ is the host molecule (rotaxane $\mathbf{1}^{4+}$ ), $\mathrm{G}$ is the guest molecule (TTF), and $\mathrm{H} \cdot \mathrm{G}$ is the complex formed, the association constant can be determined by the following equation, which is valid for a "high concentration" of G:

$\frac{1}{\Delta \delta}=\frac{1}{K_{\mathrm{a}} \cdot \Delta \delta_{\max } \cdot[\mathrm{G}]_{0}}+\frac{1}{\Delta \delta_{\max }}$

where $\Delta \delta$ is the difference between the chemical shift of the host molecule $\mathrm{H}$ after addition of $n$ equivalents of $\mathrm{G}$ and the chemical shift of free $\mathrm{H}, \Delta \delta_{\max }$ is the difference between the chemical shift of the totally complexed host molecule $\mathrm{H}$ and the chemical shift of free $\mathrm{H},[\mathrm{G}]_{0}$ is the total concentration of $\mathrm{G}$, and $K_{\mathrm{a}}$ is the association constant. Plotting $\frac{1}{\Delta \delta}$ as a function of $\frac{1}{[\mathrm{G}]_{0}}$ allows determination of both $K_{\mathrm{a}}$ and $\Delta \delta_{\max }$ (Figure 4). The calculation was carried out by using the chemical shift of the $6-\mathrm{H}$ proton, as it is this proton that experiences the greatest chemical shifts differences upon complexation (Figure 4). The association constant was shown to be about $115 \pm 20 \mathrm{M}^{-1}$ in dichloromethane. This value is significantly lower than the association constant of TTF with $\mathrm{CBPQT}^{4+}$ in acetone, which is $2600 \mathrm{M}^{-1} \cdot{ }^{[4 \mathrm{~b}, 4 \mathrm{c}]}$ From calculation of the association constant and $\Delta \delta_{\max }$, it was determined that after the addition of 83 equiv. of TTF, $90 \%$ of rotaxane $\mathbf{1}^{4+}$ was complexed. We thus estimated that the chemical shift of the TTF proton inside the cavity is about $0 \mathrm{ppm}$, meaning that the signal of this proton was shifted upfield by more than $6 \mathrm{ppm}$ by intercalation between the [4]rotaxane plates. This observation is in line with the close proximity between the host lateral aromatic groups (1,10-phenanthrolines and pyrazines) and the TTF guest.

The ability of exTTF (3) to be intercalated inside rotaxane $\mathbf{1}^{4+}$ was also investigated by ${ }^{1} \mathrm{H}$ NMR spectroscopy in $\mathrm{CD}_{2} \mathrm{Cl}_{2}$. Contrary to TTF, the chemical shifts of exTTF did not seem to be affected by the presence of rotaxane $\mathbf{1}^{4+}$ during the titration. Addition of 15 equiv. of 3 did not change significantly the ${ }^{1} \mathrm{H}$ NMR spectrum of rotaxane $\mathbf{1}^{4+}$, indicating that no intercalation process takes place. At first sight, this result could appear surprising, given that this potential guest is a an electron donor similar to TTF and should therefore also interact with electron-deficient groups. However, the shapes of these molecules are significantly different, which leads to different behaviors. Indeed, TTF is flat, ${ }^{[11]}$ whereas exTTF has a curved shape that is particularly well adapted to interaction with nonplanar electron acceptors such as fullerene, ${ }^{[12]}$ but apparently not (a)

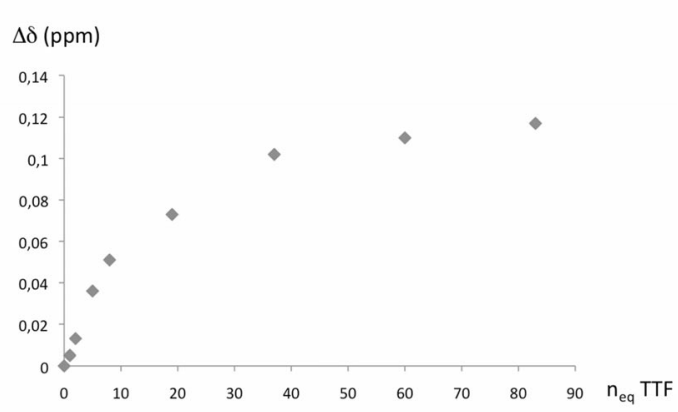

(b)

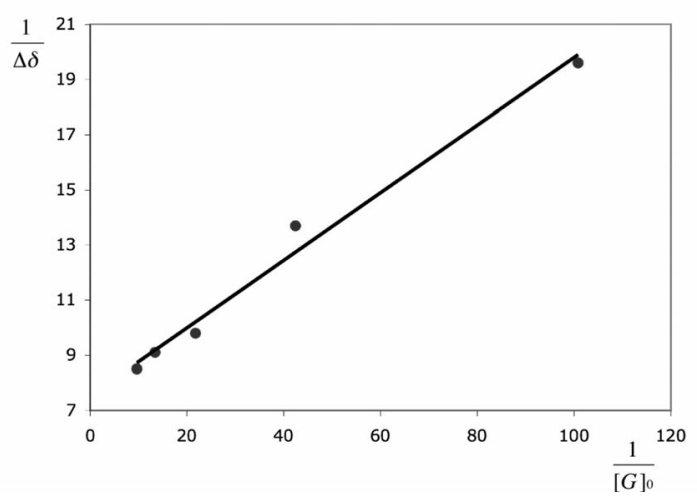

Figure 4. (a) Evolution of the chemical shift of the 6-H proton upon addition of TTF in $\mathrm{CD}_{2} \mathrm{Cl}_{2}$; (b) plot of $\frac{1}{\Delta \delta}$ as a function of $\frac{1}{[\mathrm{G}]_{0}}$ from 8 to 83 equiv. of TTF.

with $\mathbf{1}^{4+}$. The planar electron-deficient groups and the thin complexation site of $\mathbf{1}^{4+}$ are not suitable for the recognition of 3. Indeed, exTTF is probably too voluminous to easily enter the narrow cavity of $\mathbf{1}^{4+}$.

\section{Conclusions}

It has been shown that rotaxane $\mathbf{1}^{4+}$, with its electronaccepting lateral walls, can interact with a flat electron donors such as TTF. ${ }^{1} \mathrm{H}$ NMR spectroscopy of $\mathbf{1}^{4+}$ in the presence of variable amounts of TTF clearly demonstrated that complexation of this guest occurs inside the cavity formed by the two central plates of the bismacrocycles. Although the stability constant of the complex is relatively weak compared to systems containing strongly positively charged electron-acceptor groups, the association constant is significant. By contrast, a gauche electron donor such as exTTF was unable to penetrate the narrow electron-poor cavity of the [4]rotaxane receptor. Based on the present systems, it could be envisioned that, by threading appropriate TTF derivatives, more complex rotaxanes could be synthesized, for which the threaded ring would be [4]rotaxane $\mathbf{1}^{4+}$ itself.

Supporting Information (see footnote on the first page of this article): ${ }^{1} \mathrm{H}$ NMR spectroscopic assignment of $\mathbf{1}^{4+}$ and partial ${ }^{1} \mathrm{H}$ NMR spectrum of $\mathbf{1}^{4+}$. 


\section{Acknowledgments}

Y. T. and D. C. thank the Ministry of Education for PhD fellowships.

[1] a) T. Enoki, A. Miyazaki, Chem. Rev. 2004, 104, 5449-5478; b) M. Iyoda, M. Hasegawa, Y. Miyake, Chem. Rev. 2004, 104, 5085-5114; c) N. Martín, L. Sánchez, M. Á. Herranz, B. Illescas, D. M. Guldi, Acc. Chem. Res. 2007, 40, 1015-1024.

[2] a) M. Asakawa, P. R. Ashton, V. Balzani, A. Credi, C. Hamers, G. Mattersteig, M. Montalti, A. N. Shipway, N. Spencer, J. F. Stoddart, M. S. Tolley, M. Venturi, A. J. P. White, D. J. Williams, Angew. Chem. 1998, 110, 357; Angew. Chem. Int. Ed. 1998, 37, 333-337; b) V. Balzani, A. Credi, G. Mattersteig, O. A. Matthews, F. M. Raymo, J. F. Stoddart, M. Venturi, A. J. P. White, D. J. Williams, J. Org. Chem. 2000, 65, 19241936; c) I. Aprahamian, W. R. Dichtel, T. Ikeda, J. R. Heath, J. F. Stoddart, Org. Lett. 2007, 9, 1287-1290.

[3] For a nonexhaustive overview of this topic, see: a) J. L. Segura, N. Martín, Angew. Chem. 2001, 113, 1416; Angew. Chem. Int. Ed. 2001, 40, 1372-1409; b) M.-J. Blesa, B.-T. Zhao, M. Allain, F. Le Derf, M. Sallé, Chem. Eur. J. 2006, 12, 1906-1914; c) D. Canevet, M. Sallé, G. Zhang, D. Zhang, D. Zhu, Chem. Commun. 2009, 2245-2269; d) L. G. Jensen, K. A. Nielsen, T. Breton, J. L. Sessler, J. O. Jeppesen, E. Levillain, L. Sanguinet, Chem. Eur. J. 2009, 15, 8128-8133; e) M. Hardouin-Lerouge, P. Hudhomme, M. Sallé, Chem. Soc. Rev. 2011, 40, 30-43.

[4] a) D. Philp, A. M. Z. Slawin, N. Spencer, J. F. Stoddart, D. J. Williams, J. Chem. Soc., Chem. Commun. 1991, 1584-1586; b) P.-L. Anelli, M. Asakawa, P. R. Ashton, R. A. Bissell, G. Clavier, R. Górski, A. E. Kaifer, S. J. Langford, G. Mattersteig, S. Menzer, D. Philp, A. M. Z. Slawin, N. Spencer, J. F. Stoddart, M. S. Tolley, D. J. Williams, Chem. Eur. J. 1997, 3, 1113-1135; c) W. Devonport, M. A. Blower, M. R. Bryce, L. M. Goldenberg, J. Org. Chem. 1997, 62, 885-887; d) R. Wolf, M. Asakawa, P. R. Ashton, M. Gómez-López, C. Hamers, S. Menzer,
I. W. Parsons, N. Spencer, J. F. Stoddart, M. S. Tolley, D. J. Williams, Angew. Chem. 1998, 110, 1018; Angew. Chem. Int. Ed. 1998, 37, 975-979; e) H. Van Anda, A. J. Myles, J. Rebek Jr., New J. Chem. 2007, 31, 631-633.

[5] a) J. Frey, C. Tock, J.-P. Collin, V. Heitz, J.-P. Sauvage, J. Am. Chem. Soc. 2008, 130, 4592-4593; b) J.-P. Collin, J. Frey, V. Heitz, J.-P. Sauvage, C. Tock, L. Allouche, J. Am. Chem. Soc. 2009, 131, 5609-5620.

[6] a) J.-P. Collin, F. Durola, J. Frey, V. Heitz, F. Reviriego, J.-P. Sauvage, Y. Trolez, K. Rissanen, J. Am. Chem. Soc. 2010, 132, 6840-6850; b) J.-P. Collin, F. Durola, V. Heitz, F. Reviriego, J.P. Sauvage, Y. Trolez, Angew. Chem. Int. Ed. 2010, 49, 1017210175.

[7] A. J. Moore, M. R. Bryce, J. Chem. Soc. Perkin Trans. 1 1991, $157-168$.

[8] J. Frey, C. Tock, J.-P. Collin, V. Heitz, J.-P. Sauvage, K. Rissanen, J. Am. Chem. Soc. 2008, 130, 11013-11022.

[9] a) M. Yoshizawa, K. Kumazawa, M. Fujita, J. Am. Chem. Soc. 2005, 127, 13456-13457; b) J. M. Spruell, A. Coskun, D. C. Friedman, R. S. Forgan, A. A. Sarjeant, A. Trabolsi, A. C. Fahrenbach, G. Barin, W. F. Paxton, S. K. Dey, M. A. Olson, D. Benítez, E. Tkatchouk, M. T. Colvin, R. Carmielli, S. T. Caldwell, G. M. Rosair, S. G. Hewage, F. Duclairoir, J. L. Seymour, A. M. Z. Slawin, W. A. Goddard III, M. R. Wasielewski, G. Cooke, J. F. Stoddart, Nature Chem. 2010, 2, 870879.

[10] a) R. Mathur, E. D. Becker, R. B. Bradley, N. C. J. Li, J. Phys. Chem. 1963, 67, 2190-2194; b) M. W. Hanna, A. L. Ashbaugh, J. Phys. Chem. 1964, 68, 811-816; c) L. Fielding, Tetrahedron 2000, 56, 6151-6170.

[11] R. Viruela, P. M. Viruela, R. Pou-Amerigo, E. Orti, Synth. Met. 1999, 103, 1991-1992.

[12] E. M. Pérez, A. L. Capodilupo, G. Fernández, L. Sánchez, P. M. Viruela, R. Viruela, E. Ortí, M. Bietti, N. Martín, Chem. Commun. 2008, 4567-4569.

Received: January 31, 2011

Published Online: March 16, 2011 